\title{
Mechanisms for the Maintenance and Eventual Degradation of Neurofilament Proteins in the Distal Segments of Severed Goldfish Mauthner Axons
}

\author{
Tim D. Raabe, ${ }^{1}$ Tri Nguyen, ${ }^{1}$ Cullen Archer, ${ }^{1}$ and George D. Bittner ${ }^{1,2,3}$ \\ ${ }^{1}$ Departments of Zoology and ${ }^{2}$ Pharmacology, and 3 Institute for Neuroscience, The University of Texas at Austin, Austin, \\ Texas 78712-1064
}

\begin{abstract}
Cellular mechanisms that might affect the degradation of neurofilament proteins (NFPs) were examined in the distal segments of severed goldfish Mauthner axons (M-axons), which do not degenerate for more than 2 months after severance. Calpain levels, as determined by reactivity to a polyclonal antibody, remained constant for $80 \mathrm{~d}$ postseverance in distal segments of $\mathrm{M}$-axons and then declined from 80 to $85 \mathrm{~d}$ postseverance. Calpain activity in rat brain, as determined by a spectrophotometric assay, was much higher than calpain activity in control and severed goldfish brain, spinal cord, muscle, or $\mathrm{M}$-axons. Calpain activity was extremely low in $\mathrm{M}$-axons compared with that in all other tissues and remained low for up to $80 \mathrm{~d}$ postseverance in distal segments of M-axons. Phosphorylated NFPs, as determined by Stains-All treatment of SDS gels, were maintained for up to $72 \mathrm{~d}$ postseverance and then
\end{abstract}

decreased noticeably at $75 \mathrm{~d}$ postseverance when NFP breakdown products appeared on silver-stained gels. By $85 \mathrm{~d}$ postseverance, phosphorylated NFPs no longer were detected, and NFP breakdown products were the most prominent bands on silver-stained gels. These results suggest that the distal segments of $\mathrm{M}$-axons survive for months after severance, because NFPs are maintained in a phosphorylated state that stabilizes and protects NFPs from degradation by low levels of calpain activity in the $\mathrm{M}$-axon; the distal segments of severed $\mathrm{M}$-axons degenerate eventually when NFPs no longer are maintained in a phosphorylated state and become susceptible to degradation, possibly by low levels of calpain activity in the M-axon.

Key words: neurofilament protein; phosphorylation; calpain; axotomy; goldfish Mauthner axon; Wallerian degeneration
Neurofilaments are a subclass of intermediate filaments unique to neurons (Steinert and Roop, 1988; Eagles et al., 1990). Neurofilaments are composed of neurofilament proteins (NFPs), which become highly phosphorylated on entering the axon (Sternberger and Sternberger, 1983; Lee et al., 1987). The phosphorylation of NFPs regulates the polymerization and stability of the neurofilament network (Nixon and Sihag, 1991). The phosphorylation of NFPs also protects NFPs from proteolysis (Goldstein et al., 1987; Greenwood et al., 1993), whereas dephosphorylation of NFPs increases their susceptibility to degradation by calpain (Pant, 1988). In mammalian axons, the activation of calpain by increased calcium levels leads to Wallerian degeneration (Schlaepfer and Micko, 1978; Schlaepfer, 1979) in which the distal segment of the axon degenerates within $3 \mathrm{~d}$ after axotomy (Koeppen, 1982).

NFPs in the goldfish Mauthner axon (M-axon) consist of six proteins with molecular weights of $235,145,123,105,80$, and 60 kDa (Moehlenbruck et al., 1994; Raabe et al., 1995). NFPs in the goldfish $\mathrm{M}$-axon are phosphorylated by endogenous kinases in Mauthner axoplasm (M-axoplasm; Raabe and Bittner, 1995) and are degraded by calpain in vitro and in vivo (Raabe et al., 1995).

\footnotetext{
Received Oct. 30, 1995; accepted Nov. 29, 1995

This work was supported by an Advanced Technology Project Grant to G.D.B. We thank Dr. Sandy Tanner (Laboratory of Molecular and Cellular Neurobiology, NINDS-National Institutes of Health) and Dr. Joseph R. Koke (Department of Biology, Southwest Texas State University) for providing helpful comments in the preparation of this manuscript. We also thank Dr. Naren Banik (Department of Neurology, Medical University of South Carolina) for kindly providing the polyclonal antibody to milli calpain used in this study.

Correspondence should be addressed to George D. Bittner, Department of Zoology, The University of Texas at Austin, Austin, TX 78712-1064.

Copyright (C) 1996 Society for Neuroscience $0270-6474 / 96 / 161605-09 \$ 05.00 / 0$
}

Unlike distal segments of mammalian axons, which degenerate within $3 \mathrm{~d}$ after severance, the distal segments of $\mathrm{M}$-axons remain intact ultrastructurally and electrophysiologically for months after severance in goldfish maintained at $14-20^{\circ} \mathrm{C}$ (Zottoli et al., 1987; Blundon et al., 1990). NFPs remain intact biochemically in the distal segments of severed $\mathrm{M}$-axons maintained at $15-20^{\circ} \mathrm{C}$, and the degradation of NFPs in the distal segments after 2 months postseverance coincides with the degeneration of the distal segments of M-axons (Moehlenbruck et al., 1994). Assuming that NFPs are synthesized exclusively in the Mauthner cell body, maintenance of the biochemical integrity of NFPs for more than 2 months in distal segments of $\mathrm{M}$-axons maintained at $15-20^{\circ} \mathrm{C}$ could be explained by low levels of endogenous calpain, high levels of an endogenous calpain inhibitor (e.g., calpastatin), and/or the maintenance of phosphorylated NFPs, which are less susceptible to proteolysis by calpain. In contrast, the degradation of NFPs after 2 months in distal segments of M-axons maintained at $15-20^{\circ} \mathrm{C}$ could be explained by increased levels of calpain, decreased levels of calpastatin, or a decrease in phosphorylated NFPs at this time.

The present study using Stain-All treatment of SDS gels confirms a previous report (Raabe and Bittner, 1995) using inhibitors of protein kinases that showed that that NFPs are phosphorylated in control $\mathrm{M}$-axons. We also report that the ability of endogenous calpain to degrade exogenous azocasein (called calpain activity) is very low in $\mathrm{M}$-axons compared with other goldfish tissues such as brain, spinal cord, and muscle. Furthermore, calpain activity in all these goldfish tissues is much less than calpain activity in rat brain. Calpain activity in distal segments of $\mathrm{M}$-axons maintained at $14-16^{\circ} \mathrm{C}$ remains constant for up to $80 \mathrm{~d}$ postscverance, whereas 
calpain levels remain constant for $80 \mathrm{~d}$ postseverance and then decline from 80 to $85 \mathrm{~d}$ postscverance. NFPs in control (intact) M-axons are heavily phosphorylated. NFPs in distal segments of severed $\mathrm{M}$-axons remain phosphorylated for at least $72 \mathrm{~d}$ postseverance; by $75 \mathrm{~d}$ postseverance, the level of NFP phosphorylation in distal segments of $\mathrm{M}$-axons is noticeably reduced, and NFP breakdown products appear on silver-stained gels. By $85 \mathrm{~d}$ postseverance, NFP phosphorylation is no longer detected in distal segments of $\mathrm{M}$-axons, and the most prominent bands on silverstained gels contain NFP breakdown products. These results suggest that the distal segments of severed $M$-axons survive for months at $14-16^{\circ} \mathrm{C}$, because goldfish NFPs remain intact and phosphorylated, and calpain activity is very low in the distal segments of $\mathrm{M}$-axons. Our data also suggest that a decrease in the level of NFP phosphorylation after $72 \mathrm{~d}$ postseverance coincides with the degradation of NFPs, which results in the eventual degeneration of the distal segments of M-axons by $85 \mathrm{~d}$ postscrerancc.

\section{MATERIALS AND METHODS}

Collection of samples. The paired $\mathrm{M}$-axons of goldfish (Carassius auratus) originate from cell bodies located in the medulla oblongata, cross at the midline, and traverse the length of the spinal cord. M-axons are myelinated, $50-80 \mu \mathrm{m}$ in diameter, and easily distinguishable from other axons in the spinal cord when visualized with a dissecting microscope. In goldfish anesthetized with $0.02 \%$ ethyl- $M$-aminobenzoate (MS222) (Sigma, St. Louis, MO), the spinal cord was severed about $1 \mathrm{~cm}$ caudal to the operculum by making a transverse incision through the dorsal musculature with a scalpel. This procedure produces proximal $\mathrm{M}$-axon segments $\sim 1-1.5 \mathrm{~cm}$ in length and distal $\mathrm{M}$-axon segments $\sim 5 \mathrm{~cm}$ in length (Blundon et al,, 1990; Moehlenbruck et al., 1994). Each incision was sutured, and tissue adhesive (VetBond, $3 \mathrm{M}$ ) was applied to the lesion site. Silicone grease was placed over the incision to minimize infection, and the goldfish were returned to holding tanks maintained at $14-16^{\circ} \mathrm{C}$. The 3 month survival rate of control goldfish was $\sim 100 \%$, and the 3 month survival rate for the severed goldfish was at least $90 \%$.

At various postseverance sampling times (25-85 d), the goldfish were given an anesthetic overdose of $0.04 \%$ MS222 before dissecting the brain and spinal cord. $\mathrm{M}$-axons were induced to protrude from the cut ends of the spinal cord by gently pressing on 2-3 $\mathrm{mm}$ pieces of spinal cord, and the $\mathrm{M}$-axons [including both $\mathrm{M}$-axoplasm and Mauthner sheath (Msheath)] were collected by grasping the entire $\mathrm{M}$-axon and gently pulling it out of the spinal cord. Some of these M-axons were placed in homogenizing buffer for analysis by a calpain spectrophotometric assay (see below). Other M-axons were placed in SDS sample buffer [1 mM EDTA, $2.5 \%(\mathrm{w} / \mathrm{v})$ SDS, $5 \%(\mathrm{v} / \mathrm{v}) \beta$-mercaptoethanol, $0.01 \%$ bromophenol blue, $10 \mathrm{~mm}$ Tris- $\mathrm{HCl}, \mathrm{pH} 8$ ] for analysis by SDS-PAGE. In most cases, the proximal and distal segments were kept separate and placed in 5 and 10 $\mu \mathrm{l}$, respectively, of SDS sample buffer.

Calpain spectrophotometric assay. Calpain activity was estimated by a spectrophotometric assay that uses azocasein as a substrate for endogenous calpain, as described by Moss et al. (1991). The endogenous calpain activity in tissue homogenates was obtained by measuring the amount of azo chromophore released into solution after the addition of azocasein and calcium. Samples of brain (vagal lobes, medulla, and cerebellum), spinal cord (a distal segment from the severed spinal cord), muscle (dorsal musculature), and $\mathbf{M}$-axons ( $10 \mathrm{M}$ axons per assay) were collected from control (intact) goldfish and from severed goldfish at 25,50,65, and $80 \mathrm{~d}$ postseverance. Adult rat brain also was collected to compare calpain activity in rat brain with calpain activity in samples of goldfish tissues. Each tissue sample was homogenized $(\sim 20 \% \mathrm{w} / \mathrm{v})$ on ice in $20 \mathrm{~mm}$ Tris- $\mathrm{HCl}, 1 \mathrm{~mm}$ EDTA, $5 \mathrm{~mm} \beta$-mercaptoethanol, $15 \mathrm{~mm}$ cysteine $\mathrm{HCl}$, and $0.25 \mathrm{M}$ sucrose, $\mathrm{pH}$ 7.4. A $150 \mu \mathrm{l}$ aliquot of the homogenized sample was added to $250 \mu \mathrm{l}$ of assay buffer $(50 \mathrm{~mm}$ Tris- $\mathrm{HCl}, 15 \mathrm{~mm}$ $\beta$-mercaptoethanol, $\mathrm{pH} 7.4$ ). Next, $50 \mu \mathrm{I}$ of an azocasein (sulfanilimideazocasein) (Sigma) stock solution $(20 \mathrm{mg} / \mathrm{ml})$ was added, and the assay was initiated by adding $50 \mu \mathrm{l}$ of $10 \mathrm{mM} \mathrm{CaCl}$. The samples were incubated at $25^{\circ} \mathrm{C}$ for $2 \mathrm{hr}$ and were placed on ice before adding $25 \mu \mathrm{l}$ of $15 \%$ trichloroacetic acid. The samples were maintained at $-20^{\circ} \mathrm{C}$ for 5 min and then at $4^{\circ} \mathrm{C}$ for $15 \mathrm{~min}$. The samples were centrifuged for $10 \mathrm{~min}$ at $\sim 8000 \times g$, and the supernatant was placed in a separate tube to which
$225 \mu \mathrm{l}$ of $0.5 \mathrm{M} \mathrm{NaOH}$ was added to maximize absorbance of the azo chromophore. The absorbance of the supernatant at $440 \mathrm{~nm}$ was determined and compared with that of supernatants from homogenates that were not incubated with calcium. As a positive control, parallel assays were performed by adding $0.01 \mathrm{U}$ of exogenous calpain from rabbit skeletal muscle (Sigma) to azocasein in assay buffer.

$S D S-P A G E$ and immunoblotting. Samples collected from M-axons of goldfish at various times after severance were subjected to electrophoresis on a Pharmacia Phast mini-gel system using precast 7.5\% SDS-PAGE. Some gels were silver-stained (Merril et al., 1984) for total protein profile. Other gels were transferred for immunoblot analysis to nitrocellulose membranes (Towbin et al., 1979), which were blocked with $1 \%$ powdered milk and $2.5 \%$ bovine serum albumin in PBS for $1 \mathrm{hr}$ at $37^{\circ} \mathrm{C}$. Blocked membranes were washed three times with PBS and stained overnight at room temperature with a polyclonal antibody to milli-calpain purified from myelin (gift of Dr. N. Banik, Medical University of South Carolina, Charleston, SC). Immunoblots were washed and incubated for $1 \mathrm{hr}$ at $4^{\circ} \mathrm{C}$ with goat anti-rabbit secondary antibody conjugated with horseradish peroxidase (1:5000; Sigma). Innmunoblots were washed three to five times after the secondary antibody incubation, and immunoreactive products were visualized by an enhanced chemiluminescence technique (Amersham, Arlington Heights, IL). The stained gels and the immunoblots for each time point shown in this paper are representative of two or more trials.

Stains-All treatment of SDS gels. Heavily phosphorylated mammalian NFPs (Ksiezak-Reding and Yen, 1987), other proteins (e.g., casein) containing phosphate groups (Green et al., 1973), and proteins with polyanionic sites (Campbell et al., 1983) are rather selectively stained blue or bluish-pink with Stains-All (1-ethyl-2-[3-(1-ethylnaphtho[1,2-d]thiazolin-2-ylidene)-2-methylpropenyl]-naphtho-[1,2-d]thiazolium bromide) (Sigma); most other proteins stain light pink (e.g., bovine serum albumin) or are not stained with Stains-All on SDS gels (Green et al, 1973). After treating casein (Green et al., 1973) or NFPs (Ksiezak-Reding and Yen, 1987) with alkaline phosphatase (AP) to remove phosphate groups, the blue staining band disappears. Such AP treatment to remove phosphate groups lowers the apparent kDa of NFPs in mammals (Pant, 1988; Greenwood et al., 1993) and squid (Brown and Eagles, 1986).

To determine whether NFPs in goldfish M-axons selectively stain blue with Stains-All similar to mammalian NFPs, samples of M-axoplasm were electrophoresed on SDS gels, as described in the previous section. These gels were fixed in $50 \%$ methanol and $10 \%$ acetic acid for $1 \mathrm{hr}$, rinsed three times with $25 \%$ methanol for $10 \mathrm{~min}$, and then rinsed two times with $25 \%$ methanol, $30 \mathrm{~mm}$ Tris- $\mathrm{HCl}, \mathrm{pH} 8.8$, for $10 \mathrm{~min}$. The gels were placed in a fresh Stains-All solution (25\% methanol, $7.5 \%$ formamide, $0.002 \%$ Stains-All, $30 \mathrm{~mm}$ Tris-HCl, $\mathrm{pH} 8.8$ ) in the dark for $\sim 1 \mathrm{hr}$. Using this technique, six bands in control M-axoplasm stained blue at 235, 145, 123, 105 , and $80 \mathrm{kDa}$ or light bluish-pink at $60 \mathrm{kDa}$ (Fig. $1 B$, lane 1, arrows). These six bands have been shown previously to contain NFPs (Moehlenbruck et al., 1994; Raabe et al., 1995). The same six bands that stained blue or bluish-pink with Stains-All also had intense silver-staining profiles (Fig. $1 A$, lane 1, arrows). Note that Stains-All is not as sensitive as silver staining in detecting $\mathrm{M}$-axoplasmic proteins on SDS gels, because the number of bands observed on Stains-All-treated gels is fewer than the number of bands labeled on silver-stained gels (compare Fig. 1, $A$ vs $B$ ).

To confirm that NFPs in the goldfish M-axon are phosphorylated and that only phosphorylated NFPs are stained blue or bluish-pink with Stains-All, samples of M-axoplasm $(\sim 6 \mu \mathrm{g})$ were incubated with AP for $0,5,10$, and $18 \mathrm{hr}$ at $37^{\circ}$ in dephosphorylation buffer $\left(10 \mathrm{~mm} \mathrm{MgCl}_{2}, 10\right.$ $\mu \mathrm{M} \mathrm{ZnCl} 2,1 \mathrm{~mm}$ dithiothreitol, $25 \mathrm{~mm}$ Tris-HCl, $\mathrm{pH} \mathrm{8.6,} \mathrm{which} \mathrm{contained}$ $0.1 \mathrm{mg} / \mathrm{ml}$ leupeptin, $10 \mu \mathrm{M}$ pepstatin $\mathrm{A}, 100 \mu \mathrm{M}$ phenylmethylsulfonyl fluoride, and AP (4 U; ElA grade) (Boehringer Mannheim, Indianapolis, IN). When M-axoplasm was incubated with AP for increasing lengths of time, the silver-staining intensity of the six major NFP bands at 235,145 $123,105,80$, and $60 \mathrm{kDa}$ decreased progressively with increasing incubation times (Fig. $1 A$, compare lanes 2 and 4 ). In contrast to the progressive decrease in silver-stain intensity of these six NFP bands, we observed a progressive increase in silver-stain intensity of the novel bands when $\mathrm{M}$-axoplasm was treated with AP for increasing periods of time. These novel bands had lower molecular weights (Fig. $1 A$, lanes 2 and 4, arrowheads) compared with NFPs in control M-axoplasm (Fig. 1A, lane 1, arrows) or NFPs in M-axoplasm incubated for $18 \mathrm{hr}$ without AP (Fig. 1A, lane 5). When these same samples of $\mathrm{M}$-axoplasm were treated with Stains-All, the blue or bluish-pink staining of the six NFP bands decreased with increasing AP incubation times (Fig. $1 B$, compare lanes 2 and 4). In addition, novel pink staining bands (probably containing 
A

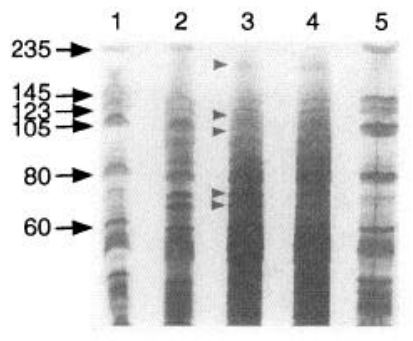

B

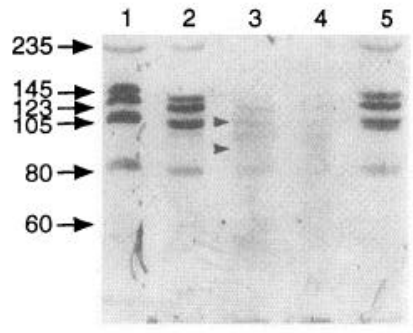

A
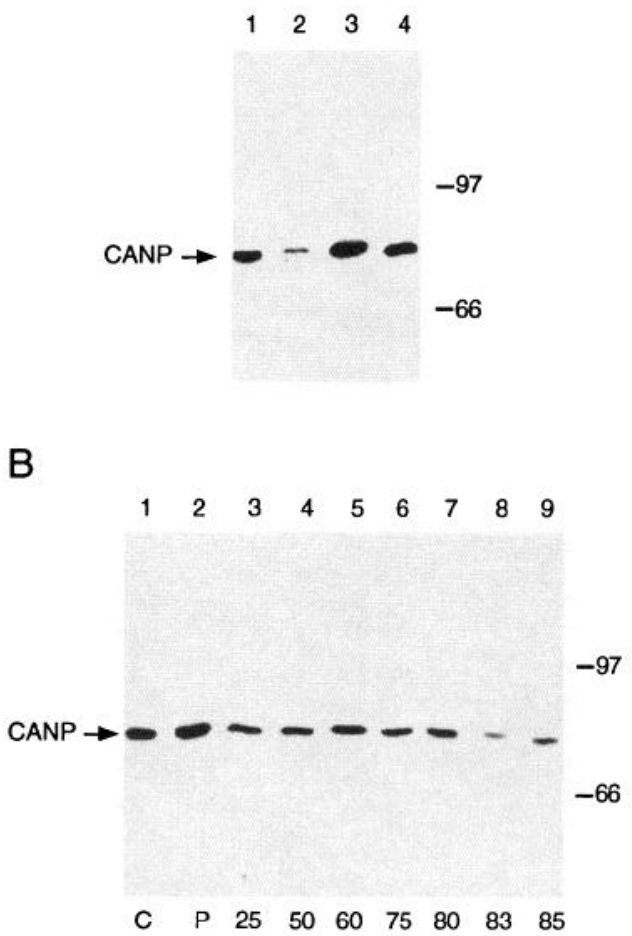

Figure 2. This is a black-and-white photograph of a gel that has stains in various shades of pinks and blues. Immunoblot of control samples $(A)$ and distal segments of $\mathrm{M}$-axons maintained at $14-16^{\circ} \mathrm{C}$ for up to $85 \mathrm{~d}$ postseverance $(B)$ reacted with a polyclonal antibody to milli-calpain (CANP). $A$, Immunoblot of control M-sheath (lane 1), control M-axoplasm (lane 2), control M-axon (lane 3), and exogenous milli-calpain from rabbit skeletal muscle (lane 4). Arrow to the left of the immunoblot points to anti-CANP reactive band at $\sim 80 \mathrm{kDa}$ in control M-sheath (lane 1), control $\mathrm{M}$-axoplasm (lane 2), and control M-axon (lane 3). Exogenous calpain (lane 4) was used as a positive control to identify calpain. $B$, Immunoblot of control $\mathrm{M}$-axon $(C$, lane 1$)$, proximal segments of $\mathrm{M}$-axons severed for $85 \mathrm{~d}(P$, lane 2$)$, and distal segments of $\mathrm{M}$-axons severed for 25-85 d (lanes 3 to 9). Arrow to the left of the immunoblot points to anti-CANP reactive band at $\sim 80 \mathrm{kDa}$ in control $\mathrm{M}$-axon (lane 1 ) and in proximal segments of $\mathrm{M}$-axons severed for $85 \mathrm{~d}$ (lane 2). Anti-CANP reactive band also is observed in distal segments of M-axons severed for $25 \mathrm{~d}$ (lane 3), $50 \mathrm{~d}$ (lane 4), $65 \mathrm{~d}$ (lane 5), $75 \mathrm{~d}$ (lane 6), and $80 \mathrm{~d}$ (lane 7). Intensity of anti-CANP reactive band is reduced in distal segments of M-axons severed for $83 \mathrm{~d}$ (lane 8 ) and $85 \mathrm{~d}$ (lane 9). Molecular weight standards (97 and $66 \mathrm{kDa}$ ) are given as labeled bars on the far right of this immunoblot.

3 , respectively). The intensity of calpain immunoreactivity was greatest in samples of control $\mathrm{M}$-axon (Fig. $2 A$, lane 3 ) compared with M-sheath (Fig. 2A, lane 1 ) or M-axoplasm (Fig. 2A, lane 2), presumably because $\mathrm{M}$-axon samples were a composite of M-axoplasm and M-sheath, both of which contained calpain. As a positive control for antibody specificity, calpain from rabbit skeletal muscle (Sigma) was included on each immunoblot (Fig. 2A, lane 4).

Calpain immunoreactivity was examined in the distal segments of severed $\mathrm{M}$-axons from seven goldfish maintained at $14-16^{\circ} \mathrm{C}$ for $25,50,65,75,80,83$, or $85 \mathrm{~d}$ postseverance. In distal segments of severed $\mathrm{M}$-axons, the intensity of the calpain immunoreactive band remained constant for $80 \mathrm{~d}$ postseverance (Fig. $2 B$, lanes 3-7) compared with control $\mathrm{M}$-axons (Fig. 2B, lane 1 ) and to proximal segments of $\mathrm{M}$-axons maintained for $85 \mathrm{~d}$ postseverance (Fig. 2B, lane 2). The intensity of the calpain immunoreactive band in distal segments of M-axons declined from 80 to $85 \mathrm{~d}$ postseverance (Fig. 2B, lanes 7-9). $\sim 80 \mathrm{kDa}$ on immunoblots of samples of control M-sheath, control $\mathrm{M}$-axoplasm, and control (intact) M-axon (Fig. 2A, lanes 1, 2, and

\section{RESULTS}

The effects of M-axon severance on the levels of calpain wer estimated by observing the intensity of immunoreactive products produced by a polyclonal antibody directed against milli-calpain purified from myelin. The antibody detected calpain in a band at

Figure 1. This is a black-and-white photograph of a gel that has stains in
various shades of pinks and blues. Silver-stained SDS gel $(A)$ and StainsAll-treated SDS gel $(B)$ from incubations of M-axoplasm with AP. $A$, silver-stained SDS gel of control M-axoplasm (lane 1), $5 \mathrm{hr}$ AP incubation $18 \mathrm{hr}$ incubation without AP (lane 5). Control M-axoplasm has six prominent bands at $235,145,123,105,80$, and $60 \mathrm{kDa}$ (lane 1, arrows). M-axoplasm incubated with AP for $5 \mathrm{hr}$ (lane 2), $10 \mathrm{hr}$ (lane 3), and $18 \mathrm{hr}$ electrophoretic mobility after removal of phosphate groups. M-axoplasm that for control M-axoplasm (lane 1). B. Stains-All-treated SDS gel of control M-axoplasm (lane 1), $5 \mathrm{hr}$ AP incubation (lane 2), $10 \mathrm{hr}$ AP without AP (lane 5). Control M-axoplasm has five prominent bands at 235 , $145,123,105$, and $80 \mathrm{kDa}$ that stain blue and one band at $60 \mathrm{kDa}$ that with AP for $5 \mathrm{hr}$ (lane 2), $10 \mathrm{hr}$ (lane 3), and $18 \mathrm{hr}$ (lane 4) have diminished bands that stain pink (arrowheads). M-axoplasm incubated for $18 \mathrm{hr}$ on SDS gels. (5) Our Stains-All technique is much less sensitive than our silver-staining technique in detecting dephosphorylated NFPs and other nonphosphorylated proteins on SDS gels. 


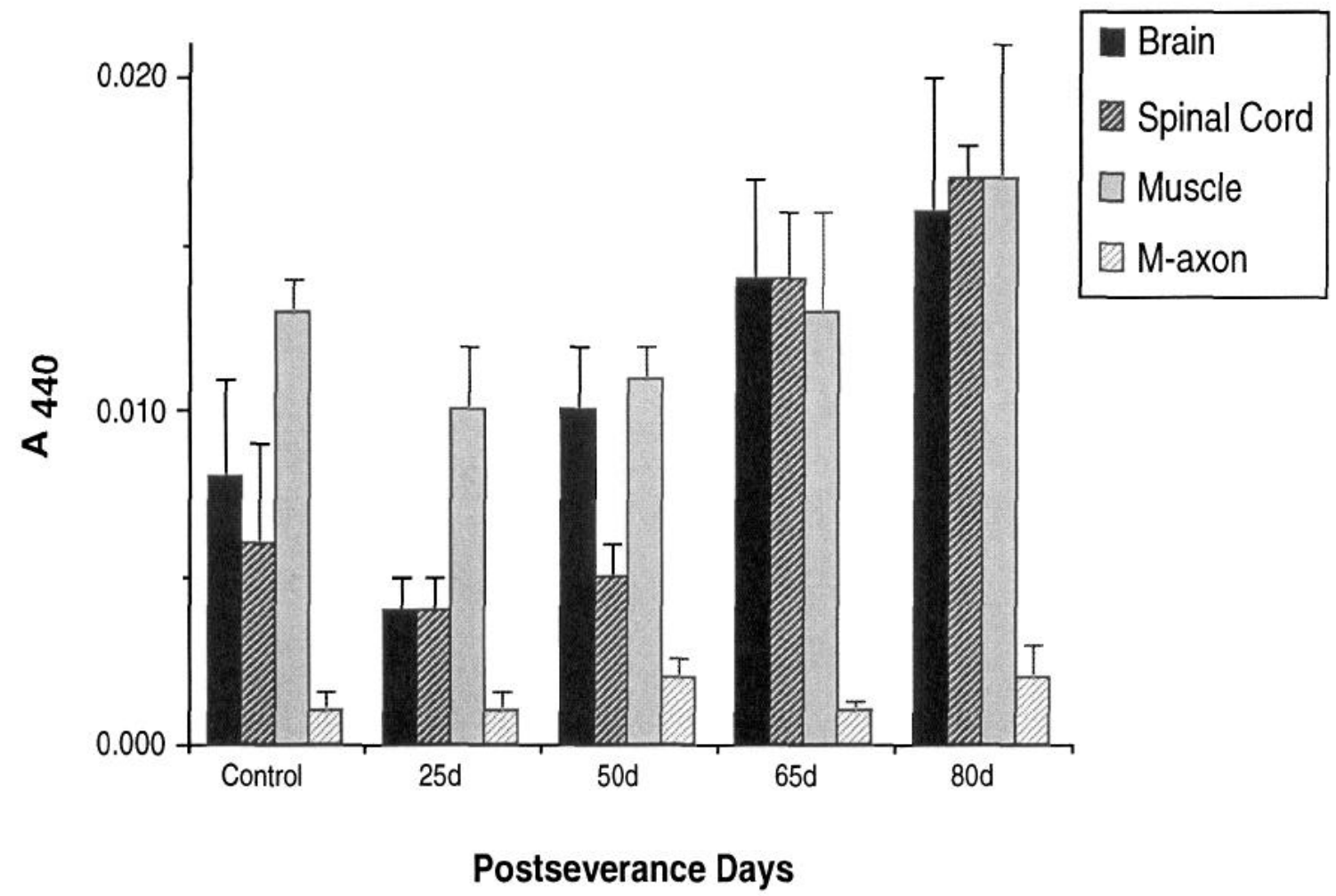

Figure 3. Calpain activity in goldfish brain, spinal cord, muscle, and $\mathrm{M}$-axons versus postseverance time in days. Calpain activity was measured as the absorbance $\left(\mathrm{OD}_{440}\right)$ of azo chromophore released from the proteolysis of azocasein. Calpain activity in samples $(n=5$ for each tissue) of control goldfish brain, spinal cord, muscle, and M-axons is represented by the bars on the far left of graph. Calpain activity in samples of severed goldfish brain, spinal cord, muscle, and M-axons plotted for increasing postseverance times of 25 ( $n=3$ for each tissue), $50(n=3), 65(n=2)$, and $80(n=2) \mathrm{d}$ from left to right. Error bars represent SEM.

\section{Calpain activity in distal segments of severed M-axons}

Calpain activity (defined as the ability of endogenous calpain to degrade azocasein) was analyzed using a spectrophotometric assay in homogenates $(20 \% \mathrm{w} / \mathrm{v})$ of brain, spinal cord, muscle, and $\mathrm{M}$-axons from both control goldfish and goldfish with a severed spinal cord (severed goldfish) maintained at $14-16^{\circ} \mathrm{C}$ for 25,50 , 65 , and $80 \mathrm{~d}$ postseverance.

Compared with tissue samples from control goldfish, calpain activity in brain, spinal cord, and muscle from severed goldfish decreased initially at $25 \mathrm{~d}$ postseverance but then increased with increased postseverance time up to $80 \mathrm{~d}$. In contrast, calpain activity in distal segments of $\mathrm{M}$-axons remained at low levels at all postseverance times (Fig. 3). For example, in brain homogenates from severed goldfish at $25 \mathrm{~d}$ postseverance, calpain activity decreased by $50 \%$ compared with control levels. Calpain activity in brain from severed goldfish increased by $25 \%$ at $50 \mathrm{~d}$ postseverance and had increased significantly $(p<0.05)$ by $100 \%$ at $80 \mathrm{~d}$ postseverance compared with levels in control brain. In spinal cord homogenates from severed goldfish, calpain activity was not significantly different from control levels at $25 \mathrm{~d}$ postseverance but increased significantly $(p<0.05)$ by 133 and $183 \%$ at 65 and $80 \mathrm{~d}$, respectively, postseverance. Calpain activity in both muscle and distal segments of M-axons from severed goldfish were not significantly different $(p>0.05)$ from control values for either tissue at any postseverance time.

Calpain activity in control samples of goldfish brain and muscle was significantly higher $(p<0.05)$ than calpain activity in control $\mathrm{M}$-axons. The calpain activity in control goldfish spinal cord was higher $(p<0.10)$ than the calpain activity in control M-axons. With the exception of calpain activity in brain at $25 \mathrm{~d}$ postseverance, calpain activity in goldfish tissues at any given postseverance time was significantly higher $(p<0.05-0.001)$ than calpain activity in distal segments of severed $\mathrm{M}$-axons at that same postseverance time. At $25 \mathrm{~d}$ postseverance, the calpain activity in goldfish brain was higher $(p<0.10)$ than the calpain activity in distal segments of severed M-axons. Calpain activity $\left(A_{440}=0.036\right)$ in a sample of intact rat brain was at least two times higher than calpain activity $\left(A_{440}=0.001-0.017\right)$ in any intact or severed goldfish tissue and was at least 10 times higher than calpain activity in distal segments of severed M-axons at any postseverance time.

\section{Phosphorylated NFPs in distal segments of severed $\mathbf{M}$-axons}

Stains-All, a carbocyanine dye, heavily stains phosphorylated mammalian NFPs blue (Ksiezak-Reding and Yen, 1987) and stains nonphosphorylated proteins red or not at all (Green et al., 1973). Previous studies (Moehlenbruck et al., 1994; Raabe and Bittner, 1995; Raabe et al., 1995) (Fig. 1) have shown that axoplasm isolated from control $\mathrm{M}$-axons and from the distal segments of severed M-axons contain NFPs in six bands at 235, 145, 123, 105,80 , and $60 \mathrm{kDa}$. The color and intensity of the Stains-All reaction with these six bands were used as a qualitative measure of NFP phosphorylation in control M-axons and in distal segments of severed M-axons.

In control M-axoplasm, the five NFP-containing bands at 235, $145,123,105$, and $80 \mathrm{kDa}$ stained intensely blue (Fig. 4A, lane 1 , 

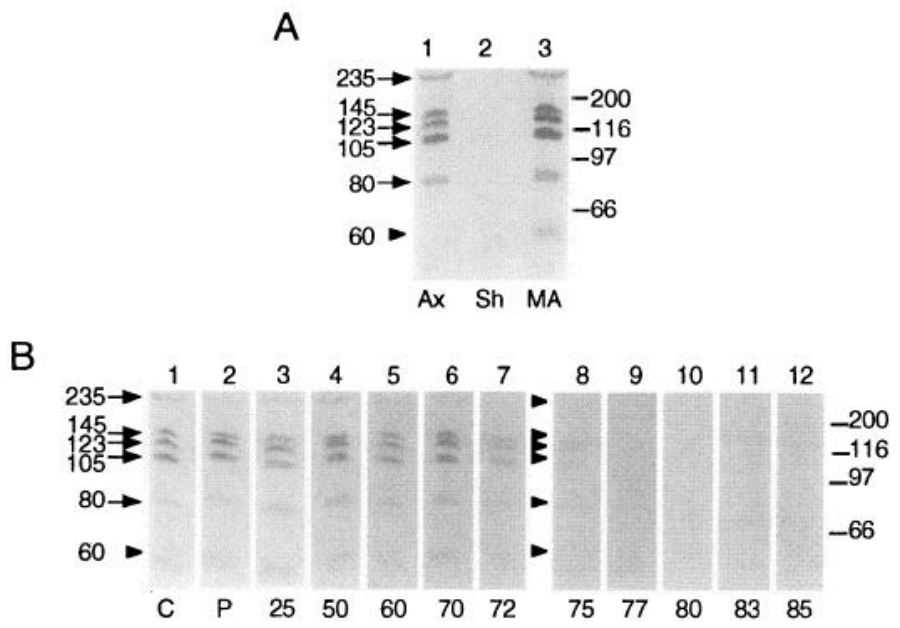

Figure 4. This is a black-and-white photograph of a gel that has stains in various shades of pinks and blues. Stains-All-treated SDS gel of control samples $(A)$ and of distal segments of M-axons maintained at $14-16^{\circ} \mathrm{C}$ for up to $85 \mathrm{~d}$ postseverance $(B)$. A, Stains-All-treated samples of control M-axoplasm (Ax, lane 1), control M-sheath (Sh, lane 2), and control $\mathrm{M}$-axon $(M A$, lane 3). Control $\mathrm{M}$-axoplasm has five intensely stained blue bands at $235,145,123,105$, and $80 \mathrm{kDa}$ (lane 1, arrows) and one lightly stained bluish-pink band at $60 \mathrm{kDa}$ (lane 1, arrowhead). Control M-sheath has no blue or bluish-pink staining bands (lane 2). Control M-axon (lane 3 ) has staining pattern similar to that for control M-axoplasm (lane I). Molecular weight standards $(200,116,97,66$, and $43 \mathrm{kDa})$ are given as labeled bars on the far right of this and other SDS gels. $B$, Stains-Alltreated samples of control $\mathrm{M}$-axon $(C$, lane 1$)$, proximal segments of $\mathrm{M}$-axons severed for $85 \mathrm{~d}(P$, lane 2$)$, and distal segments of $\mathrm{M}$-axons severed for 25-85 d (lanes 3-12). Control M-axon (lane 1) and proximal segments of $\mathrm{M}$-axons severed for $85 \mathrm{~d}$ (lane 2) have five blue-staining bands at $235,145,123,105$, and $80 \mathrm{kDa}$ (arrows) and one light bluishpink-staining band at $60 \mathrm{kDa}$ (arrowheads). Distal segments of M-axons severed for $25 \mathrm{~d}$ (lane 3), $50 \mathrm{~d}$ (lane 4), $65 \mathrm{~d}$ (lane 5), $70 \mathrm{~d}$ (lane 6), and 72 $\mathrm{d}$ (lane 7) have similar staining pattern to that for control M-axon (lane 1) and for proximal segments of M-axons severed for $85 \mathrm{~d}$ (lane 2). Arrowheads to the left of lane 8 point to blue and bluish-pink bands of reduced staining intensity observed in distal segments of $\mathrm{M}$-axons severed for $75 \mathrm{~d}$ (lane 8). Distal segments of M-axons severed for $77 \mathrm{~d}$ (lane 9), $80 \mathrm{~d}$ (lane 10), $83 \mathrm{~d}$ (lane 11), and $85 \mathrm{~d}$ (lane 12) have no bands that stain either blue or bluish-pink.

arrows), whereas the NFP-containing band at $60 \mathrm{kDa}$ stained lightly bluish-pink with Stains-All (Fig. 4A, lane 1, arrowhead). These and other data (see Fig. 1 and Materials and Methods) suggest that the five heavily blue-staining bands at 235, 145, 123, 105 , and $80 \mathrm{kDa}$ in control M-axoplasm contain highly phosphorylated NFPs, whereas the lightly bluish-pink-staining band at 60 $\mathrm{kDa}$ contains an NFP not as highly phosphorylated compared with the other NFPs. Samples of control M-sheath did not contain any bands that stained blue or red (Fig. $4 A$, lane 2); samples of control $\mathrm{M}$-axon (M-axoplasm and $\mathrm{M}$-sheath) (Fig. 4A, lane 3 ) stained in a pattern similar that for control M-axoplasm (Fig. 4A, lane 1). These results suggested that the Stains-All data obtained from samples of M-axons collected from control goldfish or from distal segments of severed goldfish were equivalent to Stains-All data obtained from samples of M-axoplasm collected from control goldfish or from distal segments of severed goldfish. Microdissection of M-axoplasm from distal segments of a severed M-axon was more difficult at longer postseverance times, because the $\mathrm{M}$-axoplasm began to disintegrate, whereas the $\mathrm{M}$-sheath remained intact. Hence, we microdissected the entire M-axon in severed goldfish to ensure that all disintegrating $\mathrm{M}$-axoplasmic proteins were analyzed in the distal stumps of severed M-axons.
The color and the intensity of the six NFP-containing bands labeled with Stains-All were examined in distal segments of severed $\mathrm{M}$-axons from 10 goldfish maintained at $14-16^{\circ} \mathrm{C}$ for 25,50 , $65,70,72,75,77,80,83$, or $85 \mathrm{~d}$ postseverance. The five NFPcontaining bands in the distal segments of severed M-axons maintained for 25 to $72 \mathrm{~d}$ postseverance always stained blue at 235,145 , 123,105 , and $80 \mathrm{kDa}$, whereas the NFP at $60 \mathrm{kDa}$ always stained bluish-pink (Fig. 4B, lanes 3-7, arrows). This staining pattern of NFPs was similar to that observed in control M-axons (Fig. $4 B$, lane 1 , arrows) and to proximal segments of severed $\mathrm{M}$-axons maintained for $85 \mathrm{~d}$ postseverance (Fig. 4B, lane 2). At $75 \mathrm{~d}$ postseverance, the intensity of the six blue- or bluish-pink-staining NFP bands in the distal segments of severed $\mathrm{M}$-axons was decreased noticeably (Fig. 4B, lane 8 ). From 77 to 85 d postseverance, the six NFP bands at 235, 145, 123, 105, 80, and $60 \mathrm{kDa}$ that stained blue or bluish-pink in control $\mathrm{M}$-axons were no longer stained in the distal segments of severed M-axons (Fig. 4B, lanes 9-12). None of the six blue- or bluish-pink-staining NFP bands in control $\mathrm{M}$-axons ever stained red in a severed $\mathrm{M}$-axon, nor was any novel band ever detected (Fig. 4B, lanes 3-12) at 77-85 d postseverance on Stain-All treated gels.

\section{Total protein profile in distal segments of severed M-axons}

Distal segments of severed $\mathrm{M}$-axons from the same 10 goldfish maintained at $14-16^{\circ} \mathrm{C}$ examined with Stains-All also were silver stained to detect any alterations in the banding profile of all proteins compared with $\mathrm{M}$-axons from control goldfish. Six prominent NFP bands at 235, 145, 123, 105, 80, and $60 \mathrm{kDa}$ were observed on silver-stained gels of $\mathrm{M}$-axoplasm from control goldfish (Fig. 5A, lane 1, arrows). Samples of M-sheath from control goldfish had silver-stained bands at 100,70 to $65,55,40$, and 36 $\mathrm{kDa}$ (Fig. $5 A$, lane 2, arrowheads). The silver-stained banding pattern of samples of $\mathrm{M}$-axons from control goldfish was a composite of the banding profiles of samples of $\mathrm{M}$-axoplasm and M-sheath, i.e., heavily stained bands were observed at 235,145 , $123,105,100,80,70$ to $65,60,55,40$, and $36 \mathrm{kDa}$ (Fig. 5A, lane 3 ).

The silver-stained banding pattern for distal segments of severed $\mathrm{M}$-axons maintained for up to $72 \mathrm{~d}$ postseverance (Fig. $5 B$, lanes 3-7) was similar to the banding pattern of control M-axons (Fig. $5 B$, lane 1 ) and to the banding pattern of proximal segments of M-axons maintained for $85 \mathrm{~d}$ postseverance (Fig. 5B, lane 2). From 75 to $77 \mathrm{~d}$ postseverance (Fig. $5 B$, lanes 8 and 9 ), NFP bands at $235,145,123,105,80$, and $60 \mathrm{kDa}$ in distal segments of severed $\mathrm{M}$-axons were silver stained similar to control M-axons (Fig. $5 B$, lane 1). Novel bands that were lightly silver stained also appeared at $200 \mathrm{kDa}$ and at $45-50 \mathrm{kDa}$ in distal segments at 75-77 $\mathrm{d}$ postseverance (Fig. 5B, lanes 8 and 9, arrowheads). The intensity of these novel silver-stained bands at $200 \mathrm{kDa}$ and at $45-50 \mathrm{kDa}$ increased continuously from 75 to $85 \mathrm{~d}$ postseverance (Fig. $5 B$; compare lanes 8-12).

At the longest postseverance times examined in this study ( $80-85 \mathrm{~d})$, the pattern of M-axoplasmic bands in distal segments of severed M-axons on silver-stained gels was considerably different from control M-axons. For example, the six prominent NFP bands at $235,145,123,105,80$, and $60 \mathrm{kDa}$ in control M-axons were less intensely silver stained at $80 \mathrm{~d}$ postseverance (Fig. $5 B$, lane 10) and were undetectable in M-axons severed for 83 or $85 \mathrm{~d}$ (Fig. 5B, lanes 11 and 12). Novel bands at 200 and $45-50 \mathrm{kDa}$ stained more intensely at $80-85 \mathrm{~d}$ postseverance. In contrast to M-axoplasmic bands, M-sheath bands in distal segments at 100, 70 to $65,55,40$, and $36 \mathrm{kDa}$ stained with approximately the same 
A

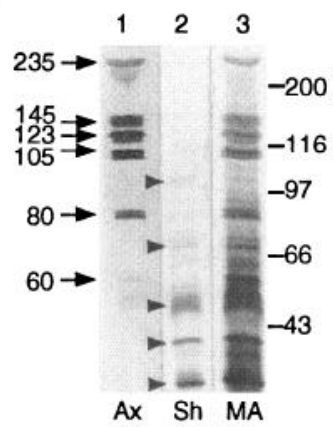

B

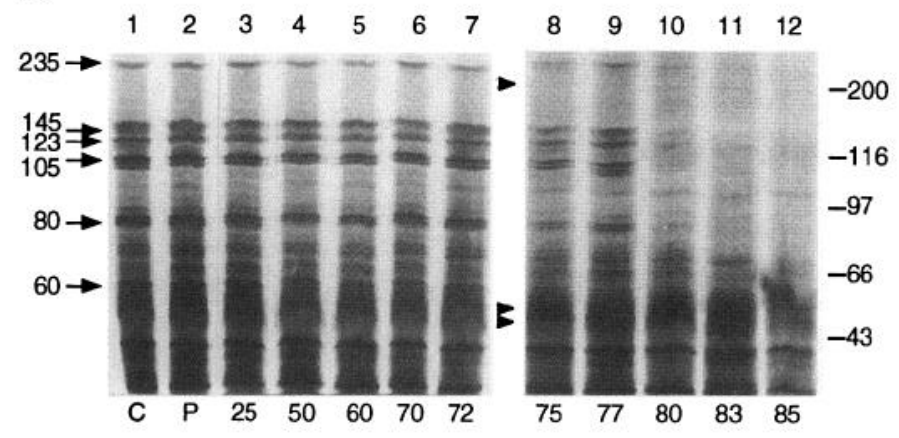

Figure 5. This is a black-and-white photograph of a gel that has stains in various shades of pinks and blues. Silver-stained SDS gel of control samples $(A)$ and of distal segments of M-axons maintained at $14-16^{\circ} \mathrm{C}$ for up to $85 \mathrm{~d}$ postseverance $(B)$. $A$, silver-stained SDS gel of control M-axoplasm (Ax, lane 1), control M-sheath (Sh, lane 2), and control $\mathrm{M}$-axon $(M A$, lane 3). Arrows in lane 1 point to the six prominent bands in M-axoplasm at 235, 145, 123, 105, 80, and $60 \mathrm{kDa}$. Arrowheads in lane 2 point to the five most heavily stained bands in control M-sheath at 100,70 , 55,40 , and $36 \mathrm{kDa}$. Bands in M-axons (lane 3) are a composite of bands in M-axoplasm and in M-sheath (compare lane 3 with lanes 1 and 2). B, Silver-stained SDS gel of control M-axon ( $C$, lane 1), proximal segments of M-axons severed for $85 \mathrm{~d}(P$, lane 2$)$, and distal segments of M-axons severed for 25-85 d (lanes 3-12). Arrows to the left of the SDS gel point to the six prominent bands in control M-axon (lane 1), in proximal segments of M-axons severed for $85 \mathrm{~d}$ (lane 2), and in distal segments of M-axons severed for 25-77 d (lanes 3-9). Arrowheads to the left of lane 8 point to the novel bands at 200 and $45-50 \mathrm{kDa}$ in distal segments of M-axons severed for $75 \mathrm{~d}$ (lane 8), $77 \mathrm{~d}$ (lane 9), $80 \mathrm{~d}$ (lane 10), $83 \mathrm{~d}$ (lane 11 ), and $85 \mathrm{~d}$ (lane 12).

intensity at all postseverance times, as observed in control M-axons (Fig. 5B; compare lane 1 with lanes 3-12).

\section{DISCUSSION}

\section{NFPs in control and severed goldfish $\mathbf{M}$-axons}

NFPs in distal segments of severed $\mathrm{M}$-axons are maintained for 65-72 d postseverance at $14-20^{\circ} \mathrm{C}$ (Fig. 5) (Moehlenbruck et al., 1994). Three general categories of cellular mechanisms could account for this long-term maintenance of NFPs in the distal segments of severed M-axons: (1) New NFPs are synthesized in the M-axoplasm, (2) New NFPs are transferred from adjacent intact cells, and/or (3) Existing or newly acquired NFPs are degraded very slowly in the M-axoplasm. The cessation of one or more of these mechanisms that maintained NFPs for $72 \mathrm{~d}$ then could account for the eventual degradation of NFPs at 75-85 d postseverance in goldfish maintained at $14-16^{\circ} \mathrm{C}$.

Our results do not rule out that the first two general mechanisms may contribute to the long-term maintenance and even- tual degradation of NFPs in distal segments of severed M-axons. However, protein synthesis often is regarded as unlikely in axons that lack polyribosomes (Peters et al., 1991); glial-axonal transfer of neuron-specific proteins (such as NFPs) synthesized in CNS glial cells also seems unlikely in a myelinated axon. Our results do suggest that the third general mechanism (slow turnover of existing or newly acquired NFPs) provides at least part of the explanation for the long-term maintenance and eventual degradation of NFPs in distal segments of severed M-axons. More specifically, the maintenance of NFPs for $72 \mathrm{~d}$ in distal segments of severed M-axons could result from low levels of calpain, high levels of calpastatin, or an inability of calpain to degrade NFPs. The eventual degradation of NFPs after $72 \mathrm{~d}$ could result from increased levels of calpain, decreased levels of calpastatin, or increased susceptibility of NFPs to proteolysis by calpain.

\section{Calpain levels and activity in intact and severed goldfish $\mathbf{M}$-axons}

Calpain, a protease found in most tissues (Nixon, 1983; Perlmutter et al., 1990), including goldfish M-axons (Raabe et al., 1995), degrades NFPs preferentially (Schlaepfer and Zimmerman, 1990). Although sudden increases in the levels of calpain in the distal segments of goldfish $\mathrm{M}$-axons maintained at $14-16^{\circ} \mathrm{C}$ theoretically could account for the degradation of NFPs beginning at about $75 \mathrm{~d}$ after severance, our data using the immunoreactivity of a polyclonal antibody (Fig. 2) show that levels of calpain remain constant in distal segments of M-axons for $80 \mathrm{~d}$ postseverance and then decline from 80 to $85 \mathrm{~d}$ postseverance. The fact that levels of calpain decrease from 80 to $85 \mathrm{~d}$ postseverance is not surprising, because other proteins in distal segments of degenerating M-axons also are degraded at this time.

Our previous studies (Raabe et al., 1995) suggested that calpain activity is low in control goldfish M-axons. Previous studies (Baudry et al., 1986) also have reported that calpain levels are low in goldfish brains compared with other vertebrate brains. Our results confirm that calpain activity is low in control goldfish brain compared with control mammalian (rat) brains. In the present study, we also find that calpain activity in control (intact) M-axons is low compared with goldfish brain, spinal cord, and muscle (Fig. 3). All these data suggest that control $\mathrm{M}$-axons have exceedingly low calpain activity compared with neurons in mammals.

Our data show that calpain activity in distal segments of $\mathrm{M}$-axons remains very low for at least $80 \mathrm{~d}$ postseverance. Because calpain activity is low for up to $80 \mathrm{~d}$ postseverance and levels of calpain remain constant for up to $80 \mathrm{~d}$ postseverance in $\mathrm{M}$-axons, our data, therefore, suggest indirectly that calpastatin levels remain constant in M-axons for at least $80 \mathrm{~d}$ postseverance. Calpain activity could increase after $80 \mathrm{~d}$ postseverance, because levels of calpastatin decrease more rapidly than levels of calpain, which also are decreasing from 80 to 85 $\mathrm{d}$ postseverance. Such an increase in calpain activity could account for the complete degradation of NFPs in distal segments of M-axons at $80-85 \mathrm{~d}$ postseverance (Blundon et al., 1990; Moehlenbruck et al., 1994). However, increases in calpain activity at $80-85 \mathrm{~d}$ postseverance might not be necessary for NFP degradation; that is, the low levels of calpain activity observed from 0 to $80 \mathrm{~d}$ postseverance might be sufficient to degrade completely less phosphorylated NFPs in distal segments of $\mathrm{M}$-axons at $80-85 \mathrm{~d}$ postseverance.

Calpain activity could be a major factor in NFP degradation in 
goldfish M-axons, because NFP breakdown products at $200 \mathrm{kDa}$ and at $45-50 \mathrm{kDa}$ appear on silver-stained gels from either (1) the distal segments of $\mathrm{M}$-axons maintained in vivo for $>2$ months at $14-20^{\circ} \mathrm{C}$ (Mochlenbruck ct al., 1994) (Fig. 5) or (2) samples of $\mathrm{M}$-axoplasm incubated in vitro with calcium or exogenous calpain (Raabe et al., 1995). Alternatively, the degradation of NFPs in M-axons at 80-85 d postseverance could be attributable to some process other than calpain degradation. For example, NFPs might be degraded by glial or leukocytic phagocytosis (Stoll and Mueller, 1986; Perry et al., 1987; Stoll et al., 1989) or by activation of the endogenous lysosomal system (Nixon and Cataldo, 1992). These same processes also might account for previous reports (Blundon et al., 1990; Moehlenbruck et al., 1994) that M-axons degenerate at $80-85 \mathrm{~d}$ postseverance in goldfish maintained at $15-20^{\circ} \mathrm{C}$.

In contrast to distal segments of severed M-axons, calpain activity increases in other goldfish tissues after severance of the spinal cord and adjacent dorsal musculature. For example, calpain activity in both brain and spinal cord from severed goldfish increases significantly, possibly because the brain and spinal cord contain cells damaged directly or indirectly by severance of the spinal cord. The moderate $(\sim 20 \%)$ increase in calpain activity in muscle from severed goldfish might explain the decrease in the mass of muscles adjacent to the spinal cord after severance (Moehlenbruck et al., 1994). Reductions in the muscle mass of tuna also are observed in a condition known as "burnt tuna," in which muscles deteriorate because of calpain activation (Watson et al., 1992).

\section{NFP phosphorylation and degradation in severed goldfish $\mathbf{M}$-axons}

As described previously, NFPs in the distal segments of severed goldfish $\mathrm{M}$-axons at $14-16^{\circ} \mathrm{C}$ begin to degrade at $75 \mathrm{~d}$ postseverance, even though levels of calpain and calpain activity remain constant for at least $80 \mathrm{~d}$ postseverance. These data suggest that some processes other than increased calpain lcvels or decreased calpastatin levels are responsible for NFP degradation from 75 to $85 \mathrm{~d}$ postseverance. As mentioned previously, NFPs might be degraded at 75-85 d postseverance through phagocytosis or by lysosomal proteases. NFPs also might be degraded, because they are maintained no longer in a highly phosphorylated state. In other preparations, phosphorylation of NFPs can stabilize the neurofilanent network (Nixon and Sihag, 1991) and protect NFPs from proteolysis (Goldstein et al., 1987; Pant, 1988). Phosphorylated mammalian NFPs form a blue complex with Stains-All, but the intensity of blue staining decreases as phosphate groups are removed from mammalian NFPs; once mammalian NFPs lose $\sim 50 \%$ of their phosphate content, Stains-All no longer is able to bind to the NFPs (Ksiezak-Reding and Yen, 1987).

Phosphorylated NFPs are detected as five blue-staining bands at $235,145,123,105$, and $80 \mathrm{kDa}$ and one bluish-pink band at 60 $\mathrm{kDa}$ in control $\mathrm{M}$-axons and in distal segments of goldfish $\mathrm{M}$-axons for up to $72 \mathrm{~d}$ postseverance. These same six bands also are labeled heavily on silver-stained gels; the intensity of the silver stain and the banding pattern are similar for control M-axons and for distal segments of $\mathrm{M}$-axons severed for up to $72 \mathrm{~d}$ postseverance. All these data suggest that phosphorylated NFPs are maintained for up to $72 \mathrm{~d}$ postseverance in distal segments of $\mathrm{M}$-axons in goldfish maintained at $14-16^{\circ} \mathrm{C}$.

At $75 \mathrm{~d}$ postseverance, the intensity of the blue or bluish-pink Stains-All reaction product decreases for all six NFP bands. The silver-stained intensity does not change for these same six bands, and novel silver-stained bands appear at $200 \mathrm{kDa}$ and at $45-50$ $\mathrm{kDa}$. These novel bands do not react with Stains-All, suggesting that these novel bands do not contain heavily or lightly phosphorylated NFPs. Previous studies (Moehlenbruck et al., 1994; Raabe et al., 1995) show that these novel silver-stained bands at $200 \mathrm{kDa}$ and at $45-50 \mathrm{kDa}$ almost certainly are NFP breakdown products, because these bands react with the $\alpha$-intermediate filament antigen antibody. All these data suggest that NFP phosphorylation decreases and that some NFPs are degraded in distal segments of $\mathrm{M}$-axons maintained for $75 \mathrm{~d}$ postseverance.

At $77 \mathrm{~d}$ postseverance, Stains-All no longer reacts with any band in distal segments of severed $\mathrm{M}$-axons. In contrast, bands at $235,145,123,105,80$, and $60 \mathrm{kDa}$ silver stained, as are novel bands at $200 \mathrm{kDa}$ and at $45-50 \mathrm{kDa}$, which might contain NFP breakdown products. These data suggest that the level of NFP phosphorylation falls below the detection level of Stains-All, but that NFPs are not degraded completely at $77 \mathrm{~d}$ postseverance.

At $80 \mathrm{~d}$ postseverance, the silver-stained intensity of the six NFP bands obviously is decreased compared with control $\mathrm{M}$-axons. At 83-85 d postseverance, these six NFP bands are not detectable on silver-stained gels. The silver-stained intensity of the novel bands at $200 \mathrm{kDa}$ and at $45-50 \mathrm{kDa}$ increases continuously from 80 to $85 \mathrm{~d}$ postseverance. In contrast, Stains-All does not bind to any band in distal segments of $\mathrm{M}$-axons from 80 to 85 d postseverance. All these data suggest that less phosphorylated NFPs are susceptible to degradation in distal segments of M-axons from 80 to $85 \mathrm{~d}$ postseverance.

In summary, our data are consistent with the following hypothesis: NFPs are maintained for $72 \mathrm{~d}$ in severed goldfish $\mathrm{M}$-axons at $14-16^{\circ} \mathrm{C}$, because these NFPs are phosphorylated and therefore are less susceptible to proteolysis by low levels of calpain activity. From 75 to $85 \mathrm{~d}$ postseverance, NFPs become increasingly dephosphorylated and are degraded, possibly by low levels of calpain activity in the distal segments of severed goldfish M-axons.

The ability of NFPs to remain phosphorylated for up to $72 \mathrm{~d}$ postseverance could be attributed to decreased phosphatase activity in the distal segments of severed $\mathrm{M}$-axons compared with intact $\mathrm{M}$-axons. Similar reductions in phosphatase activity have been reported for distal segments of severed mammalian axons (for review, see Koeppen, 1982). Alternatively, in control $\mathrm{M}$-axons and in distal segments of severed M-axons, interactions between receptors on an intact axolemma and the myelin sheath could activate a kinase system that phosphorylates NFPs, as hypothesized for myelinated mammalian axons (deWaegh et al., 1992; Nixon et al., 1994). The sudden loss of NFP phosphorylation in $\mathrm{M}$-axons at $75 \mathrm{~d}$ postseverance could be attributable to the loss of this glial-axonal interaction necessary for the kinase system to remain active (de Waegh et al., 1992). In addition, kinases responsible for phosphorylating NFPs could be degraded and not resynthesized, or the source of phosphate (e.g., ATP) could be depleted and not replenished after $72 \mathrm{~d}$ postseverance.

\section{Mechanisms for axonal maintenance and degeneration in goldfish versus mammals}

The distal segments of severed M-axons survive according to both ultrastructural and physiological measures for many months in goldfish maintained at $14-20^{\circ} \mathrm{C}$ (Zottoli et al., 1987; Blundon et al., 1990; Moehlenbruck et al., 1994). Recent work by Moehlenbruck et al. (1994) suggests that the biochemical maintenance of 
NFPs in the distal segments of severed M-axons may be crucial for the survival of the entire distal segment of the severed M-axon. Our data suggest that maintenance of phosphorylated NFPs in the distal segments of $\mathrm{M}$-axons render neurofilaments less susceptible to degradation by extremely low levels of calpain; maintenance of intact NFPs would provide stability to the neurofilament network (Nixon and Sihag, 1991), which provides structural integrity to the axon (Lazarides, 1980). Our data suggest that dcphosphorylation of NFPs leads to degradation of NFPs after $72 \mathrm{~d}$ at $14-16^{\circ} \mathrm{C}$ and that this degradation is complete by $80-85 \mathrm{~d}$ postseverance. This complete degradation of NFPs correlates with the complete collapse of the entire distal segment of M-axons for 80-85 d postseverance.

In contrast to goldfish $\mathrm{M}$-axons, distal segments of severed mammalian axons typically degenerate within 1-3 d (Koeppen, 1982). In mammals, axotomy rapidly decreases the phosphorylation state of NFPs in the distal segment of the severed axon (Goldstein et al., 1987; Gold et al., 1993). Compared with that in goldfish M-axons, increased proteolysis of dephosphorylated NFPs in mammalian axons that have higher calpain activity could account for the rapid decrease in neurofilaments and concomitant degeneration of severed distal segments of mammalian axons (Schlaepfer, 1979; Schlaepfer and Micko, 1979).

Additional support for the role of calpain in the degeneration of distal segments of severed axons comes from studies by Banik et al. (1994) and Glass et al. (1994). Banik et al. (1994) used a corticosteroid (methylprednisolone) to inhibit calpain activity directly in experimentally induced spinal cord injury in rats. The inhibition of calpain activity was correlated with a reduced rate of NFP degradation, which could retard the rate of CNS axonal degeneration after spinal cord injury. Glass et al. (1994) have reported that the delayed degeneration of severed axons in the Ola mutant mouse may be attributable to a reduced sensitivity of calpain to calcium. For example, compared with wild-type mice, higher levels of calcium are required to activate calpain and for the complete degradation of NFPs by calpain in severed axons from Ola mice. Data from both these studies (Banik et al., 1994; Glass et al., 1994) are consistent with our hypothesis that low calpain activity in the M-axon in conjunction with high levels of NFP phosphorylation could account for the maintenance of NFPs and distal segments of $\mathrm{M}$-axons severed for up to $72 \mathrm{~d}$ at $14-16^{\circ} \mathrm{C}$. The loss of NFP phosphorylation at $75 \mathrm{~d}$ postseverance then could increase the susceptibility of NFPs to degradation by low calpain activity. The degradation of dephosphorylated NFPs could be a primary cause of the collapse and degeneration of distal segments of goldfish $\mathrm{M}$-axons at $80-85 \mathrm{~d}$ postseverance.

\section{REFERENCES}

Banik NL, Lobo DC, Terry EC, Hogan EL (1994) Inhibition of calpain by methylprednisolone (MP). Trans Am Soc Neurochem 25:429.

Baudry M, Simonson L, Dubrin R, Lynch G (1986) A comparative study of soluble calcium-dependent proteolytic activity in brain. J Neurobiol 17:15-28.

Blundon JA, Sheller RA, Moehlenbruck JW, Bittner GD (1990) Effect of temperature on long-term survival of anucleate giant axons in crayfish and goldfish. J Comp Neurol 297:1-14.

Brown A, Eagles PAM (1986) Squid neurofilaments: phosphorylation and $\mathrm{Ca}^{2+}$-dependent proteolysis in situ. Biochem J 239:191-197.

Campbell KP, MacLennan DH, Jorgensen AO (1983) Staining of the $\mathrm{Ca}^{2+}$-binding proteins, calsequestrin, calmodulin, troponin $\mathrm{C}$, and S-100, with the cationic carbocyanine dye "Stains-all." J Biol Chem 258:11267-11273.
Caputo CB, Sygowski LA, Brunner WF, Scott CW, Salama AI (1989) Properties of several protein kinases that copurify with rat spinal cord neurofilaments. Biochim Biophys Acta 1012:299-307.

de Waegh SM, Lee VM-Y, Brady ST (1992) Local modulation of neurofilament phosphorylation, axonal caliber, and slow axonal transport by myelinating Schwann cells. Cell 68:451-463.

Eagles PAM, Pant HC, Gainer H (1990) Neurofilaments. In: Molecular biology of intermediate filaments (Goldman RD, Steinert PM, eds), pp 37-94. New York: Plenum.

Glass JD, Schryer BL, Griffin JW (1994) Calcium-mediated degeneration of the axonal cytoskeleton in the Ola mouse. $J$ Neurochem 62:2472-2475.

Gold BG, Storm-Dickerson T, Austin DR (1993) Regulation of aberrant neurofilament phosphorylation in neuronal perikarya. IV. Evidence for involvement of two signals. Brain Res 626:23 30.

Goldstein ME, Sternberger NH, Sternberger LA (1987) Phosphorylation protects neurofilaments against proteolysis. J Neuroimmunol 14:149-160.

Green MR, Pastewka JV, Peacock C (1973) Differential staining of phosphoproteins on polyacrylamide gels with a cationic carbocyanine dye. Anal Biochem 56:43-51.

Greenwood JA, Troncoso JC, Costello AC, Johnson GVW (1993) Phosphorylation modulates calpain-mediated proteolysis and calmodulin binding of the $200 \mathrm{kDa}$ and $160 \mathrm{kDa}$ neurofilament proteins. J Neurochem 61:191-199.

Kocppen AH (1982) Wallerian degencration. In: Handbook of neurochemistry, Vol 9 (Lajtha A, ed), pp 443-505. New York: Plenum.

Ksiezak-Reding H, Yen S-H (1987) Phosphatase and carbocyanine dye binding define different types of phosphate groups in mammalian neurofilaments. J Neurosci 7:3554-3560.

Lazarides E (1980) Intermediate filaments as mechanical integrators of cellular space. Nature 283:249-256.

Lee VM-Y, Carden M, Schlaepfer W (1987) Monoclonal antibodies distinguish several differentially phosphorylated states of the two largest rat neurofilament subunits (NFH and NFM) and demonstrate their existence in the normal nervous system of adult rats. J Neurosci 7:3474-3488.

Merril CR, Goldman D, Van Keuren MD (1984) Gel protein stains: silver stain. Methods Enzymol 104:441-447.

Moehlenbruck JW, Cummings JA, Bittner GD (1994) Long-term survival followed by degradation of neurofilament proteins in severed goldfish Mauthner axons. J Neurobiol 25:1637-1651.

Moss DE, Gutierrez YR, Perez RG, Kobayashi H (1991) Simple spectrophotometric assay for calcium-activated neutral proteases (calpains). Pharmacol Biochem Behav 39:495-497.

Nixon RA (1983) Proteolysis of neurofilaments. In: Neurofilaments (Marotta CA, ed), pp 117-154. Minneapolis: University of Minnesota.

Nixon RA, Cataldo AM (1992) The lysosomal system in neuronal cell death: a review. Ann NY Acad Sci 674:87-109.

Nixon RA, Sihag RK (1991) Neurofilament phosphorylation: a new look at regulation and function. Trends Neurosci 14:501-506.

Nixon RA, Paskevich PA, Sihag RK, Thayer CY (1994) Phosphorylation on carboxyl terminus domains of neurofilament proteins in retinal ganglion cell neurons in vivo: influences on regional neurofilament accumulation, interneurofilament spacing, and axon caliber. $J$ Cell Biol 126:1031-1046.

Pant HC (1988) Dephosphorylation of neurofilament proteins enhances their susceptibility to degradation by calpain. Biochem $\mathbf{J}$ 256:665-668.

Pant HC, Shecket G, Gainer H, Lasek RJ (1978) Neurofilament prolein is phosphorylated in the squid giant axon. J Cell Biol 78:R23-R27.

Pant HC, Gallant PE, Gainer H (1986) Characterization of a cyclic nucleotide- and calcium-independent neurofilament protein kinase activity in axoplasm from the squid giant axon. J Biol Chem 261:2968-2977.

Perlmutter LS, Gall C, Baudry M, Lynch G (1990) Distribution of calcium-activated protease calpain in rat brain. J Comp Neurol 296:269-276.

Perry VH, Brown MC, Gordon S (1987) The macrophage response to central and peripheral nerve injury: a possible role for macrophages in regeneration. J Exp Med 165:1218-1223.

Peters A, Palay SL, Webster HF (1991) The fine structure of the nervous system, 3rd Ed. New York: Oxford UP.

Raabe TD, Bittner GD (1995) Phosphorylation of neurofilament proteins in isolated goldfish Mauthner axon. J Neurochem, in press. 
Raabe TD, Nguyen T, Bittner GD (1995) Calcium-activated proteolysis of neurofilament proteins in goldfish Mauthner axons. J Neurobiol 26:253-261.

Schlaepfer WW (1979) Nature of mammalian neurofilaments and their breakdown by calcium. Prog Neuropathol 4:101-123.

Schlaepfer WW, Micko S (1978) Chemical and structural changes of neurofilaments in transected rat sciatic nerve. J Cell Biol 78:369-378.

Schlaepfer WW, Micko S (1979) Calcium-dependent alterations of neurofilament proteins in rat peripheral nerve. $J$ Neurochem 32:211-219.

Schlaepfer WW, Zimmerman U-JP (1990) The degradation of neurofilaments b calpains. In: Intracellular calcium-dependent proteolysis (Mellgren RL, Murachi T, eds), pp 241-249. Boca Raton, FL: CRC.

Steinert PM, Roop DR (1988) Molecular and cellular biology of intermediate filaments. Annu Rev Biochem 57:593-625.

Sternberger L, Sternberger N (1983) Monoclonal antibodies distinguish phosphorylated and nonphosphorylated forms of neurofilaments in situ. Proc Natl Acad Sci USA 80:6126-6130.
Stoll G, Mueller HW (1986) Macrophages in the peripheral system and astroglia in the central nervous system of rat commonly express apolipoprotein $\mathrm{E}$ during development but differ in their response to injury. Neurosci Lett 72:233-238.

Stoll G, 'lrapp BD, Griffin JW (1989) Macrophage function during Wallerian degeneration of rat optic nerve: clearance of degenerating myelin and Ia expression. J Neurosci 9:2327-2335.

Towbin H, Staehlin T, Gordon J (1979) Electrophoretic transfer of proteins from polyacrylamide gels to nitrocellulose sheets: procedure and some applications. Proc Natl Acad Sci USA 76:4350-4354.

Watson CL, Morrow HA, Brill RW (1992) Proteolysis of skeletal muscle in yellowfin tuna (Thunnus albacares): evidence of calpain activation. Comp Biochem Physiol 103B:881-887.

Zottoli SJ, Marek L, Agostini M, Strittmatter S (1987) Morphological and physiological survival of goldfish Mauthner axons isolated from their somata by spinal cord crush. J Comp Neurol 255:272-282. 